\title{
Challenges and Opportunities for Community Empowerment Practices in Indonesia during the Covid-19 Pandemic through Strengthening the Role of Higher Education
}

\author{
Arifin Saleh ${ }^{1}$, Mujahiddin ${ }^{2}$ \\ ${ }^{1}$ Dosen Prodi Kesejahteraan Sosial FISIP University of Muhammadiyah Sumatera Utara \\ ${ }^{2}$ Dosen Prodi Kesejahteraan Sosial FISIP University of Muhammadiyah Sumatera Utara \\ arifinsaleh@umsu.ac.id
}

\section{Abstract}

Covid-19 began to appear at the end of 2019 and began to spread in January 2020 precisely in Wuhan City, China. The presence of this virus has successfully paralyzed all world activities from various sectors, ranging from education, business, politics, tourism and so forth. This condition does not only occur in Indonesia but also affects all countries in the world. Of the various problems that arise in the middle of the community, it is felt necessary to provide a form of community empowerment practice. The main objective is not only to overcome problems related to economic income, but also to make people have the ability to meet their physical, economic and social needs. The practice of community empowerment is not only understood as a change activity carried out from within individuals, communities or organizations but also requires support and encouragement from outside parties, especially support from institutions that have a role in empowerment practices. One of the many institutions that have a role in the implementation of community empowerment practices is the University or in other terms referred to as Higher Education. This research method uses a literature study approach which is a series of activities related to data collection techniques through literature, reading, recording and managing research material. The data taken in this literature study comes from the provision of online media, reference books and research journals that are considered relevant to be able to answer research questions. The results of this writing indicate that Higher Education has a role in the practice of community empowerment, both directly and indirectly through the implementation of Higher Education Tridharma. It's just that, in its implementation, the role of universities in the practice of community empowerment, especially during the Pandemic Covid-19 period is not as simple as imagined. Although there are opportunities in implementing empowerment practices, of course there are also forms of challenges that will be faced by universities in implementing community empowerment practices. Therefore, at least a strategic policy step from the central government is needed that can strengthen the role of Higher Education, as well as to answer the Challenges and Opportunities for Community Empowerment Practices during the Pandemic Covid19 Through the Role of Higher Education.
\end{abstract}

Keywords

Community Empowerment; Panderic Covid-19, the Rde of Hgher Education.

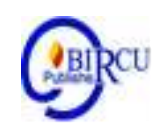

\section{Introduction}

Coronavirus or in the Indonesian term referred to as Corona Virus is a collection of viruses from the subfamilli Orthocoronavirinae in the Coronaviridae family and the order of Nidovirales. This group of viruses basically can cause disease in birds, including human 
mammals (id.wikipedia.org). In humans, this virus can cause respiratory infections from mild in nature such as colds to those of a severe and deadly nature such as SARS and MERS. Coronavirus is currently developing and experiencing changes in variation which is then referred to as Covid-19 (Corona Virus Disease in 2019). Covid-19 began to appear at the end of 2019 and began to spread in January 2020 precisely in Wuhan City, China. The presence of this virus has successfully paralyzed all world activities from various sectors, ranging from education, business, politics, tourism and so forth. This condition does not only occur in Indonesia but also affects all countries in the world. Until March 2020 Covid-19 had spread to 152 countries with a total number of 197,168 cases (Bramasta, 2020).

The large number of countries that experienced the Covid-19 case made the World Health Organization (WHO) raise the Covid-19 case from an epidemic to a pandemic (Ekarina, 2020). The rising status of Covid-19 from an epidemic to a pandemic has made many countries including Indonesia undertake various practices of protection and supervision of the region and human interaction in it with various mechanisms including; social distancing, physical distancing, regional quarantine to lockdown mechanisms. In Indonesia, in addition to the mechanism of social distancing and physical distancing, PSBB (Large-scale Social Limitation) for areas that are considered to have an emergency status are also stipulated. One of the pre-conditions that must be met by the region / region to obtain a permit to implement the PSBB is the availability of basic needs such as food in the area, the availability of health facilities and pre-facilities including mandatory masks and safeguarding the security of the citizens (CNN Indonesia, 2020).

On the other hand, the policies or steps taken by each country in dealing with Covid-19 certainly have an impact and risk for all aspects of human life. In Arum's view (2020), the Indonesian government's policy which only applies a social restriction mechanism rather than a lockdown is a policy choice aimed at reducing the risk of economic impact on the Covid-19 case which is expected to be more severe if using a lockdown mechanism. Likewise, the economic impact of the presence of Covid-19 is now inevitable. This condition can be seen from the practice of Termination of Employment (PHK) carried out by many companies that are directly affected by Covid-19. Based on data released by the Ministry of Manpower \& BPJS Employment, there are around 2.8 million workers affected by Covid-19 due to the cessation of company operations. In detail, 2.8 million workers consisted of; 1.7 million formal workers who were laid off, 749.4 thousand formal workers laid off, 282 thousand informal workers whose businesses were disrupted, and 100 thousand migrant workers were repatriated (Jayani, 2020).

Not only in the form of measurable and clearly visible economic impacts. Another impact resulting from Covid-19 is actually also felt by many individuals-communities such as increased anxiety, stress and panic that is included in this context is Panic Buying. Accurate data about the situation have not been described in research reports, but if collected in a variety of psychological opinions in the news media, it can be said that Pandemic Covid-19 threatens mental disorders. Putri (2020) wrote a report on how the emergence of panic in a person due to Covid-19 such as; emergence of behavior of someone who always brings soap and hand sanitizer wherever they go. Not only that, the condition of the body that has a fever (chills) and itching in the throat immediately raises the worry of being exposed to Covid-19. Even in other reports it is said that reading information about the symptoms of Corona (Covid-19) can make someone feel sick (Anna, 2020), even though the condition occurs is more due to psychomatic disorders (Anggraini, 2020).

The various problems that arise in the middle of the community, it is felt necessary to provide a form of community empowerment practice. The main objective is not only to overcome problems related to economic income, but also to make people have the ability to 
meet their physical, economic and social needs, such as; increase self-confidence, participate in social activities, and be able to independently carry out the tasks of life (Suharto, 2009).

Community empowerment is a process of creating a community with much greater control over its environment. The process demands organisational means in order to develop (Badaruddin et al, 2020). Therefore, the practice of community empowerment here is conceived of as an effort or way by which people, organizations and communities are directed to be able to master their lives (Damsar \& Indrayani, 2016). With this concept, the practice of community empowerment is not only understood as a change activity carried out from within individuals, communities or organizations but also requires support and encouragement from outside parties, especially support from institutions that have a role in empowerment practices. One of the many institutions that have a role in the implementation of community empowerment practices is the University or in other terms referred to as Higher Education.

Education is one of the efforts to improve the ability of human intelligence, thus he is able to improve the quality of his life. So, to create the highest quality of human resources, education is becoming an important factor to be considered. The importance of education is also reflected at MPR No. II/MPR/1993 which states that the national education aims to improve the quality of Indonesia people that is religious people, and pious to God Almighty, noble character, has high personality, discipline, work hard, responsible, independent, smart, healthy, physically and mentally healthy. (Sugiharto, 2020)

In Law No. 12 of 2012 concerning Higher Education, the relationship between the role of tertiary institutions and the practice of community empowerment is implied. This can be seen in article 5 point "c" and "d". At point "c" explained that Higher Education aims to produce science and technology through research that pays attention to and applies the value of the humanities to benefit the progress of the nation, as well as the progress of civilization and the general welfare of humanity. While at point "d", it is explained about the realization of Community Service based on reasoning and research work that is useful in advancing public welfare and intellectual life of the nation. More specifically, the role of tertiary institutions in community empowerment practices can be seen in Article 6 points "i" and "j" which explain the principles of higher education which at both points are emphasized must pay attention to the principle of partiality in economically disadvantaged groups and empowering all community component through participation in the administration and quality control of higher education services. Kariono et al (2020) states participation is a benchmark in assessing whether the development project aims to strengthen / build the community or not, because, if the community does not have the opportunity to participate in the construction of a development project in the village, the project is essentially not a community development project.

Education is a conscious effort made by adults for human maturity which is carried out in the process of teaching and learning activities, both formally and informally. Education is expected to be able to answer all the challenges of the times and be able to foster national generations, so that people become reliable and of high quality, with strong characteristics, clear identities and able to deal with current and future problems. (Azhar, 2018)

The importance of the role of universities in the practice of community empowerment was also stated by Schieffer \& Ronnie (2014) through the concept they called The Integral University, an approach that wanted a change in a university to become more integral (read; integrated) by connecting the four functions major universities namely; Education (E), Research (R), Community Activation (A), and Catalysing Development (C). The merging of the four main functions of the university is done so that the university becomes "Care" for the development of individuals, organizations, communities and communities. In the process the four main 
functions of the university are united by first categorizing the four functions based on their respective assignment areas. This is because according to Schieffer \& Ronnie (2014), the main challenge in implementing Integral University is to differentiate and integrate the four functions.

After that, Schieffer \& Ronnie (2014) argues that the education and research function must go beyond its main focus by evolving. Where education must be aligned more closely with the transformative approach that can answer contemporary problems in the dynamics of learning. Whereas research must be harmonized more closely with innovation. Therefore, Schieffer \& Ronnie (2014) suggest the two functions to carry out forms of learning and research based on community and society. (See Figure 1)

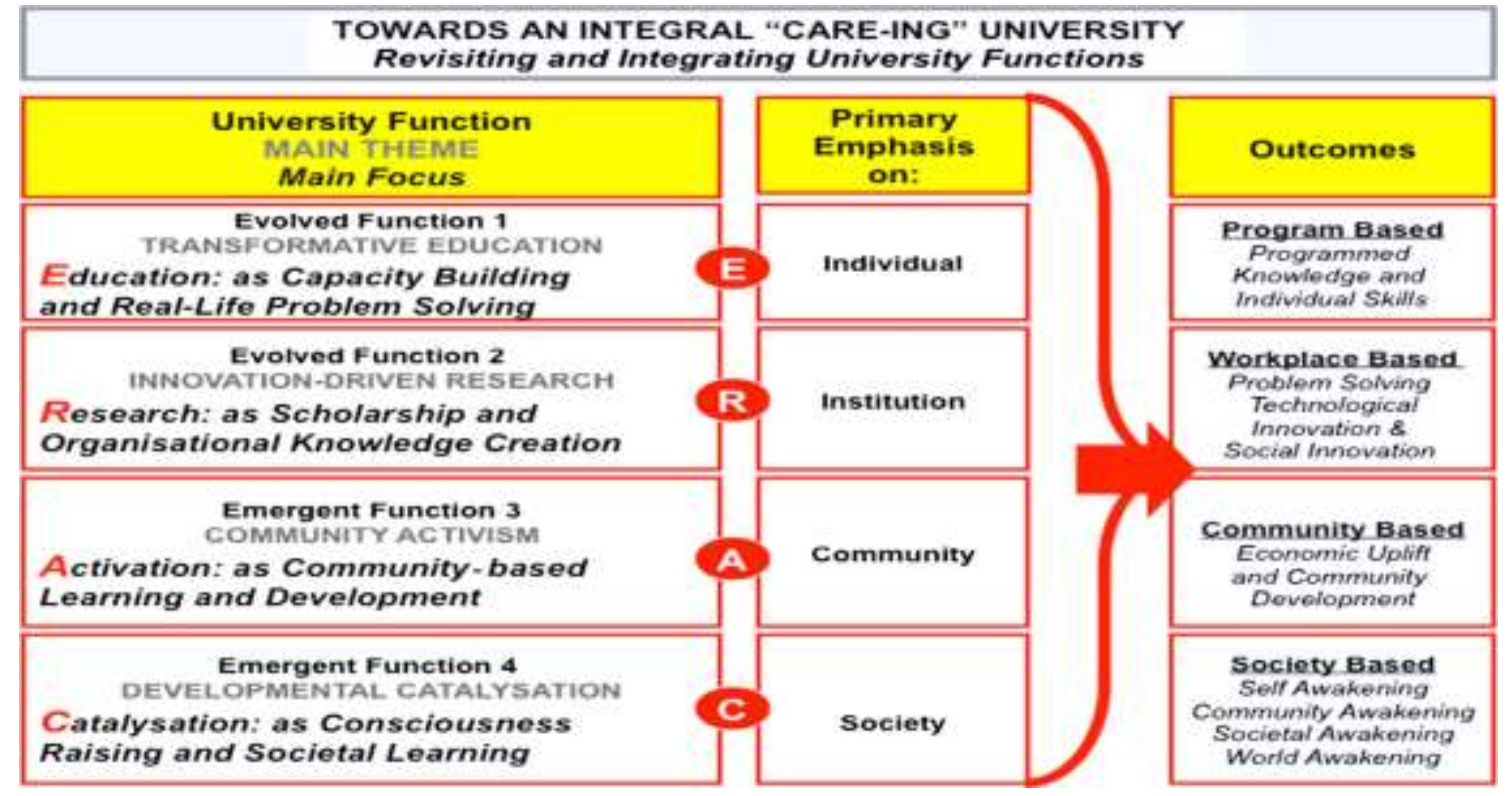

Figure 1. Towards An Integral CARE-ing University

Source: Schieffer \& Ronnie (2014)

The real role of universities in the practice of community development and empowerment can also be seen in a research report conducted by Mahmud et al, (2018) entitled: Leveraging The Human Capital Values And University's Support On Knowledge Transfer Program For Community In Malaysia. In the report Mahmud et al, (2018) concluded that human resources and university support were positively related to community development performance. Affirmative support from higher education institutions, according to Mahmud et al, (2018) ensures success in the Knowledge Transfer Program in Malayasia. On the basis of various problems and the role of universities in the practice of community empowerment, this study is interested in discussing: "Challenges and Opportunities for the Practice of Community Empowerment in Indonesia during the Pandemic Covid-19 Period Through Strengthening the Role of Higher Education.

\section{Research Method}

This research method uses a literature study approach which is a series of activities related to data collection techniques through literature, reading, recording and managing research material (Zed, 2004). The data taken in the study of this literature comes from the distribution of online media, reference books and research journals that are considered relevant to be able to answer research questions. The data is then categorized, analyzed, and then described. 


\section{Discussion}

Discussion on the results of this study will be presented based on the above research problem formulation. Following each discussion of research results:

\subsection{The Role of Higher Education in Community Empowerment Practices}

The role of universities in the practice of community empowerment can be divided into two categories, namely the role of community empowerment practices directly and the role of community empowerment practices indirectly. Referring to the Tridharma of Higher Education, the dharma of education is a form of indirect community empowerment. Where in this dharma, individuals-people who enter the Higher Education process at the university will get a knowledge transfer, strengthening skills and enhancing the experience based on knowledge practice. So that through this educational process will be born individuals who are qualified, independent and have the skills to be able to compete in the job market. This process is what is called community empowerment practice as part of the improvement of community capability (Mulyawan, 2016).

In Indonesia, efforts to create quality individuals born from tertiary institutions have been arranged in the form of the Indonesian National Qualification Framework (KKNI) which is used as a reference in the preparation of learning outcomes of graduates from each level of education nationally. The spirit of the formation of national qualifications is based on Higher Education Law No. 12 of 2012 Article 29 paragraphs (1), (2) and (3) and followed by Presidential Regulation No. 8 of 2012 which then impacts on curriculum changes and its management in each study program. The curriculum, which initially refers to the achievement of competencies, refers to learning outcomes. With the existence of standard qualifications at KKNI, it is expected that it will change the way of looking at one's competence, no longer merely a diploma but by looking at a qualification framework that is nationally agreed upon as a basis for recognition of one's educational outcomes broadly (formal, non formal, or in formal) that are accountable and transparent. Therefore, the formation of curriculum structure will greatly determine the shape and achievements of individuals such as what is wanted by a nation.

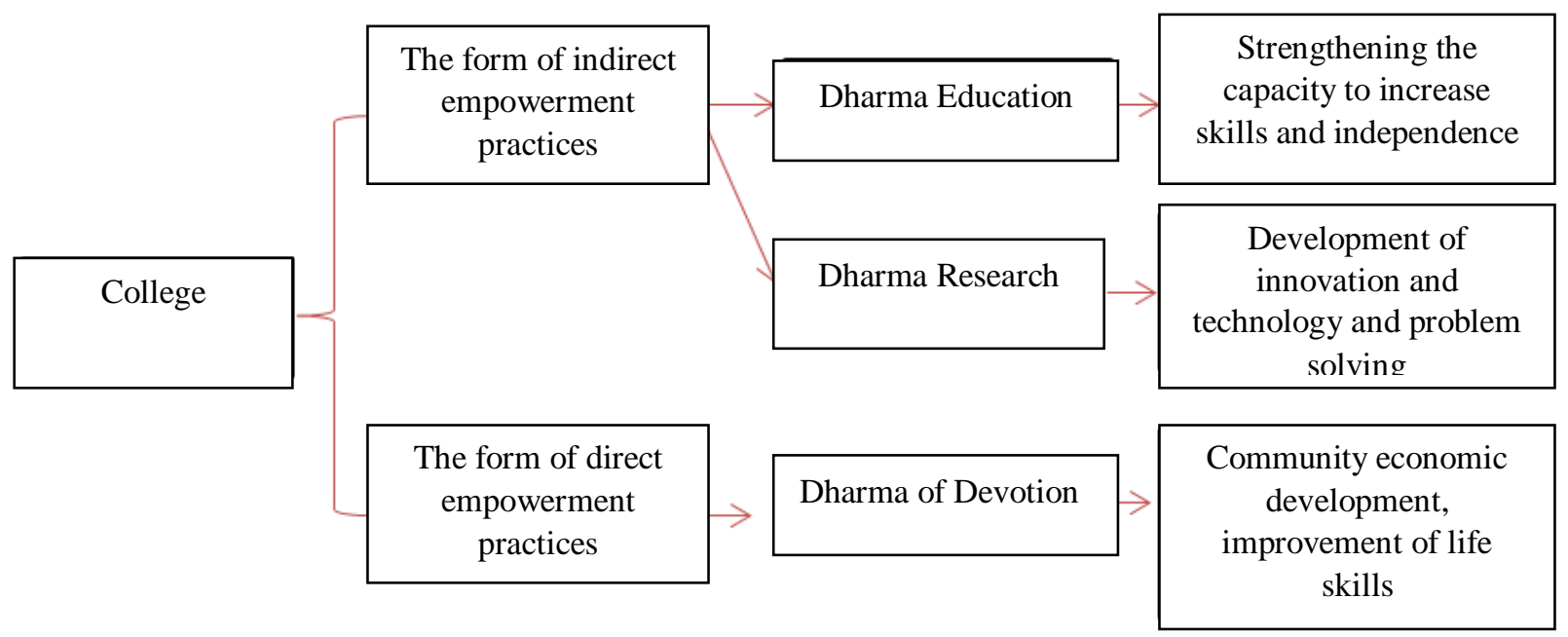

Figure 2. The Role of Higher Education in Community Empowerment Practices Source: Processed from various sources. 
In addition to the education dharma, the research dharma is also included in the form of empowering practices that are carried out indirectly by universities. Through the results of research conducted by the Higher Education Human Resources (HR-PT), it will be found patterns, models and practices of empowerment that are considered "effective" and "appropriate" for a community group. These models can be found in various research report journals. It's just that, in general implementation, there are still many development policies, especially community development, not referring to the results of tertiary research. However, if we refer to the concepts of community development using the Triple Helix approach, it will be found that the important role of universities is inseparable from the government and the private sector. At Triple Helix, higher education academics according to Murniati (2009) as intellectuals who play an important role in the development of creative industries, through the development of science, technology and research innovation.

While the role of universities in the practice of empowerment can be directly seen from the dharma of Community Service. This Dharma aims to help certain communities in various program activities without expecting anything in return. In general, service programs are designed by various universities or institutes in Indonesia to make a real contribution to the Indonesian people, especially in developing the welfare and progress of the Indonesian nation. Through various forms of dedication, it will be seen how the role played by universities, Dariah (2009) states that there is a role for universities in the Application Variation Model of Village Community Empowerment in West Java, Wasito (2008) said that universities can increase their role in society through the development of traditional medicines . While Maryati (2012) views universities as having a role in empowering entrepreneurship, especially in developing small entrepreneurs in facing global competition.

\subsection{Challenges and Opportunities for Higher Education in Implementing Community Empowerment Practices during the Covid-19 Period}

The presence of Covid-19 as a pandemic certainly has an economic, social and psychological impact on society. Therefore, the responsibility to help the community in facing difficult times due to Pandemic Covid-19 is certainly a shared responsibility. Strategic policy making is certainly needed to create a conducive, safe and comfortable atmosphere for the community. In this case, Higher Education as an institution, has a significant role in providing input to the government regarding policy steps that can be taken to overcome socio-economic problems that exist in the community. This is according to Nulhaqim et al, (2016) because Universities have professionals who have studies in solving a problem and it is needed by policy makers.

On the other hand, Higher Education through its Tridharma also has a special area in providing direct practice to the community, which in the above context is referred to as a form of practice of community empowerment both directly through the implementation of dedication and indirectly through the process of education and research. But in reality, the role of universities in the practice of community empowerment, especially during the Pandemic Covid-19 period is not as simple as imagined. Although there are opportunities in implementing empowerment practices, of course there are also forms of challenges that will be faced by universities in implementing community empowerment practices.

The forms of challenges and opportunities are also quite diverse, both in the internal context of higher education and in the external context. For example, in the case of students being dismissed from campus activities to prevent the spread of Covid-19 and the introduction of online learning methods with the home system, it is certainly a challenge for many universities. Moreover, there are still many universities that do not have a good elearning system. So that most learning processes are carried out through WhatApp Gorup, 
Zoom Application and Google Classroom, all of which are not University-owned applications but are applications belonging to certain companies. These challenges naturally become an opportunity for Universities to be able to develop distance learning systems with better elearning mechanisms so that they can be felt by many people who are steakholders for Universities. The form of Challenges and Opportunities for Higher Education in Implementing Community Empowerment Practices during the Covid-19 Period can be seen in the table below:

Table 1. Challenges and Opportunities for Higher Education in Implementing Community Empowerment Practices during the Covid-19 Pandemic Period

\begin{tabular}{|c|c|c|c|}
\hline $\begin{array}{c}\text { Tridharma } \\
\text { College }\end{array}$ & Education & Research & Pengabdian \\
\hline Challenge & $\begin{array}{l}\text { - There is no distance } \\
\text { learning application } \\
\text { owned by universities } \\
\text { - Not yet compiled a } \\
\text { curriculum that can } \\
\text { prepare community } \\
\text { capabilities in the face } \\
\text { of a pandemic } \\
\text { - The absence of } \\
\text { campus standards or } \\
\text { SOPs in carrying out } \\
\text { Clean and Healthy } \\
\text { Behavior (PHBS) }\end{array}$ & $\begin{array}{l}\text { - There are not many } \\
\text { studies that lead to } \\
\text { virus development } \\
\text { technology. } \\
\text { - There are not many } \\
\text { studies that lead to the } \\
\text { development of the } \\
\text { immune system and } \\
\text { the formation of anti- } \\
\text { virus. } \\
\text { - In the social- } \\
\text { humanioar field, there } \\
\text { are no studies that } \\
\text { discuss the readiness } \\
\text { of the community, } \\
\text { political elites and the } \\
\text { state in dealing with } \\
\text { the times of the virus } \\
\text { pandemic. }\end{array}$ & $\begin{array}{l}\text { - Not yet maximal } \\
\text { community service programs } \\
\text { that lead to the } \\
\text { implementation of PHBS, } \\
\text { the establishment of disaster } \\
\text { resilient communities, } \\
\text { management / cultivation of } \\
\text { medicinal plants, and } \\
\text { improvement of community } \\
\text { clinical literacy about } \\
\text { infectious diseases. }\end{array}$ \\
\hline Opportunity & $\begin{array}{l}\text { - Preparing an } \\
\text { application-based } \\
\text { Information } \\
\text { Technology that can } \\
\text { be used in distance } \\
\text { learning methods if at } \\
\text { any time the global } \\
\text { Pandemic occurs } \\
\text { again. } \\
\text { - Develop a curriculum } \\
\text { that can shape the } \\
\text { capabilities of the } \\
\text { community in dealing } \\
\text { with Pandemic. } \\
\text { - Creating a campus that } \\
\text { has PHBS standards } \\
\text { that are measurable } \\
\text { and implemented as a } \\
\text { form of campus } \\
\text { excellence. }\end{array}$ & $\begin{array}{l}\text { - Floating studies related } \\
\text { to viruses (Covid-19) } \\
\text { and studies that } \\
\text { prepare communities } \\
\text { to deal with pandemic } \\
\text { cases. } \\
\text { - Develop studies related } \\
\text { to improving the } \\
\text { immune system and } \\
\text { anti-virus through } \\
\text { herbal medicine and } \\
\text { chemical approaches. } \\
\text { - Compile strategic } \\
\text { issues in the social- } \\
\text { humanities field that } \\
\text { are considered relevant } \\
\text { to predicting the } \\
\text { readiness of the } \\
\text { community in dealing } \\
\text { with pandemic }\end{array}$ & $\begin{array}{l}\text { - Implementation of } \\
\text { community empowerment } \\
\text { programs can be done by } \\
\text { counseling and forming } \\
\text { communities that are } \\
\text { resilient to pandemics or } \\
\text { epidemics similar to } \\
\text { Covid-19, such as; (1) } \\
\text { forming a resilient village } \\
\text { Covid-19. (2) Socialization } \\
\text { of Healthy Living, (3) } \\
\text { Enhancement of } \\
\text { Understanding of Clinical } \\
\text { Literacy, (4) Training on } \\
\text { Strengthening of the } \\
\text { Immune System. (5) } \\
\text { Management / Cultivation } \\
\text { of Medicinal Plants, (6) } \\
\text { Training on Making Masks } \\
\text { and Handsanitizers }\end{array}$ \\
\hline
\end{tabular}


To be able to answer these challenges and realize the opportunities listed above, strengthening the role of tertiary institutions is needed through strategic policy steps from the central government as the national education management authority. The strategic policy steps that we feel are important to do are as follows:

1. Scholarship quota addition for prospective students and students with various forms of policy programs. With the existence of this scholarship component, it is expected to be able to maintain the school participation rate to universities in the middle of Pandemic Covid-19.

2. Providing financial assistance / tools for state and private universities that have a faculty of medicine and hospitals so that they can conduct studies related to diseases, viruses and immune systems.

3. Prepare a learning model based on Information Technology 4.0. to support the implementation of learning when pandemic cases occur. So that it no longer depends on media / applications owned by private companies or other companies.

4. The development of this research study can be included in the RISTEK-DIKTI Research Strategic Plan as a priority issue.

\section{Conclusion}

Based on the results of the discussion above it can be concluded that Higher Education has a role in the practice of community empowerment, both directly and indirectly through the implementation of Higher Education Tridharma. It's just that, in its implementation, the role of universities in the practice of community empowerment, especially during the Pandemic Covid-19 period is not as simple as imagined. Although there are opportunities in implementing empowerment practices, of course there are also forms of challenges that will be faced by universities in implementing community empowerment practices. Therefore, at least a strategic policy step from the central government is needed that can strengthen the role of Higher Education, as well as to answer the Challenges and Opportunities for Community Empowerment Practices during the Pandemic Covid-19 Through the Role of Higher Education.

\section{References}

Arum, Riska. (2020). Pembatasan Sosial Di Indonesia Akibat Virus Corona Ditinjau Dari Sudut Pandang Politik. Diambil dari: 10.31228/osf.io/g8ny3.

Azhar,A. (2018). Students' Trends in Islamic Communication Postgraduate in2010-2016 State Islamic University of North Sumatera (UINSU). Budapest International Research and Critics Institute (BIRCI-Journal), P.206-214.

Badaruddin et al. (2020). Village community empowerment through village owned enterprise based on social capital in North Sumatera. Asia Pacific Journal of Social Work and Development.

Bramasta, Dandy Bayu. (2020, Maret 18). Update Virus Corona di Seluruh Dunia: Tembus 152 Negara, 80.840 Sembuh, 7.905 Meninggal. Kompas.com. Diambil dari: https:/www.kompas.com/tren/read/2020/03/18/080500265/update-virus-corona-diseluruh-dunia--tembus-152-negara-80.840-sembuh-7.905

CNN Indonesia. (2020, April 09). Kemendagri Rinci Syarat Daerah Sebelum Ajukan PSBB. www.cnnindonesia.com.

Diambil

dari: https://www.cnnindonesia.com/nasional/20200409134912-20-492069/kemendagririnci-syarat-daerah-sebelum-ajukan-psbb 
Damsar \& Indrayani. (2016). Pengantar Sosiologi Pedesaan. Jakarta: Kencana

Dariah, Atih Rohaeti. (2009). Peran Perguruan Tinggi dalam Aplikasi Variasi Model Pemberdayaan Masyarakat Desa di Jawa Barat. MIMBAR. Vol XXV, No 2, Bulan JuliDesember Tahun 2009, pp 143-151.

Ekarina. (2020, Maret 12). Virus Corona Meluas, WHO Tetakan Sebagai Pandemi Global. katadata.co.id. Diambil dari: https://katadata.co.id/berita/2020/03/12/virus-coronameluas-who-tetapkan-sebagai-pandemi-global

Jayani, Dwi Hadya. (2020, April 18). Kemenaker dan BPJS Ketenagakerjaan mencatat ada sekitar 2,8 juta pekerja yang terkena dampak pandemi Covid-19. katadata.co.id. Diambil dari: https://katadata.co.id/infografik/2020/04/18/wabah-phk-akibat-covid-19

Kariono et al. (2020). A study of women's potential and empowerment for accelerating village development in Serdang Bedagai district, North Sumatera Province. Community, Work \& Family.

Mahmud, Roslinah., et al. (2018). Leveraging The Human Capital Values And University's Support On Knowledge Transfer Program For Community In Malaysia. International Journal of Arts \& Sciences. 11(01), pp 279-286.

Mulyawan, Rahman. (2016). Masyarakat, Wilayah, dan Pembangunan. Bandung: UNPAD PRESS.

Murniati, Dewi Eka. (2009). Peran Perguruan Tinggi Dalam Triple Helix Sebagai Upaya Pengembangan Industri Kreatif. Diambil dari: https://eprints.uny.ac.id/5165/1/01_Dewi_Eka_Murniati.pdf

Nulhaqim, Soni Akhmad., dkk,. (2016). Peranan Perguruan Tinggi Dalam Meningkatkan Kualitas Pendidikan di Indonesia Untuk Menghadapi ASEAN COMMUNITY. Social Work Jurnal. Vol 6, No 2, Tahun 2016, pp 154-272

Schieffer, A., Lessem, R. (2014) The Integral University: Holistic development of individuals, communities, organisations and societies. Prospects 44, pp 607-626. DOI: https://doi.org/10.1007/s11125-014-9324-z

Schieffer, Alexander \& Ronnie Lessem. (2014). The Integral University: Holistic Development of Individuals, Communities, Organisations and Societies. PROSPECTS.

Suharto, Edi. (2009). Membangun Masyarakat Memberdayakan Rakyat; Kajian Strategis Pembangunan Kesejahteraan Sosial \& Pekerjaan Sosial. Bandung: Refika Aditama

Sugiharto. (2020).Geographical students' learning outcomes on basic political science by using cooperative learning model with Group Investigation (GI) type in State University of Medan, Indonesia, Journal of Human Behavior in the Social Environment, 30:4, P. 447-456.

Undang-Undang Nomer 12 Tahun 2012 Tentang Perguruan Tinggi.

Wasito, Hendri. (2008). Meningkatkan Peran Perguruan Tinggi Melalui Pengembangan Obat Tradisional. MIMBAR. Vol XXIV, No 2, Bulan Juli-Desember Tahun 2008, pp 117127.

Zed, Mestika. (2004). Metode Penelitian Kepustakaan. Jakarta: Yayasan Obor Indonesia.

Media Online 